\title{
Identification of Acanthamoeba Genotypes in Pools and Stagnant Water in Ponds in Sistan Region in Southeast Iran
}

\author{
İran`^ı Güneybatısında Yer Alan Sistan Bölgesinde Havuzlarda ve Durgun Su Birikintilerinde \\ Acanthamoeba Genotiplerinin Belirlenmesi
}

\author{
Ali Aghajani', Mansour Dabirzadeh², Yahya Maroufi ${ }^{2}$, Hossein Hooshyar ${ }^{1}$ \\ 'Department of Parasitology, Kashan University of Medical Sciences, Kashan, Iran \\ ${ }^{2}$ Department of Microbiology and Parasitology, Zabol University of Medical Sciences, Zabol, Iran
}

\section{ABSTRACT}

Objective: Acanthamoeba is one of the most abundant free-living amoebas that is widely distributed in natural and artificial environment resources. Acanthamoeba pathogenic genotypes cause chronic human diseases including amoebic keratitis and granulomatous amoebic encephalitis. The aim of this study was to determine and identify Acanthamoeba genotypes residing in pools and stagnant water in ponds in Sistan region in southeast Iran. This descriptive study was conducted at the Parasitology Laboratory, School of Medicine, Zabol University of Medical Sciences.

Methods: In this descriptive study, 93 water samples were collected from pools and ponds in Zabol, Zahak, Hirmand, Hamoon, and Nimrooz in Sistan region. Samples after filtering through $0.45-\mu \mathrm{m}$ nitrocellulose paper filters were cultured in a $1.5 \%$ non-nutrient agar medium enriched with heat-killed Escherichia coli. Polymerase chain reaction (PCR) was conducted using specialized primers for detecting the genus Acanthamoeba. The sequencing of positive samples was used for determining Acanthamoeba genotypes.

Results: From 82 free-living amoeba positive culture samples, 38 isolates were confirmed to belong to the genus Acanthamoeba by PCR. On sequencing, 34 samples (89.47\%) belonged to the T4 genotype, three (7.9\%) to the T5 genotype, and one (2.63\%) to the T3 genotype. Conclusion: All genotypes found in this study are potentially pathogenic. The T4 genotype is the main genotype of Acanthamoeba responsible for amoebic keratitis. Resource water is a potential risk factor for the distribution of free-living amoeba. Therefore, more attention of health authorities to determine, training and prevention from infection are recommended.

Keywords: Acanthamoeba, water, genotype, Sistan, Iran

Received: 28.07.2015 Accepted: 26.07.2016

ÖZ

Amaç: Acanthamoeba yaygın olarak doğal ve suni çevre kaynaklarında yayılan özgür yaşayan bir amiptir. Acanthamoeba patyojenik genotipleri amibik keratit ve granülomatöz amibik ensefalit gibi kronik insan hastalıklarına neden olurlar. Bu çalışmanın amacı, İran'ın güneydoğusunda yer alan Sistan bölgesinde havuzlarda ve durgun su birikintilerinde bulunan Acanthamoeba genotiplerini belirlemek ve tanımlamaktır. Bu tanımlayıcı çalışma Zabul Tıp Bilimleri Üniversitesi Tıp Fakültesinde yer alan Parazitoloji Laboratuarında yapılmışıır.

Yöntemler: Bu tanımlayıcı çalışmada, Sistan bölgesinde yer alan Zabol, Zahhak, Hirmand, Hamoon ve Nimrooz'daki havuzlardan ve su birikintilerinden 93 numune alındı. Numunelerin kültürleri, 0.45- $\mu \mathrm{m}$ nitroselüloz filtre kağıdı ile süzüldükten sonra, ısıyla öldürülmüş Escherichia coli ile zendinleştirilmiş \%1,5 non-nutrient agar ortamında yapıldı. Polimeraz zincir reaksiyonu (PZR), Acanthamoeba türünü saptamak için özelleştirilmiş primerler kullanılarak yapıldı. Acanthamoeba genotiplerini belirlemek amacıyla pozitif numune dizilimi kullanıldı.

Bulgular: Seksen iki özgür yaşayan amip pozitif kültür örneğinden 38 izolatın, Acanthamoeba türü olduğu PZR ile doğrulandı. Dizilimde, 34 $(\% 89,47)$ numunenin T4 genotipine, üç $(\% 7,9)$ numunenin T5 genotipine ve bir $(\% 2,63)$ numunenin de T3 genotipine ait olduğu belirlendi. Sonuç: Bu çalışmada bulunan tüm genotipler potansiyel olarak patojeniktir. T4 genotipi, amibik keratitten sorumlu olan başlıca Acanthamoeba genotipidir. Su kaynakları özgür yaşayan amipin dağılması açısından potansiyel bir risk faktörüdür. Bu nedenle, sağlık yetkililerinin bu konuya dikkat etmeleri ve enfeksiyondan korunma konusunda eğitime daha çok önem vermeleri önerilmektedir.

Anahtar kelimeler: Acanthamoeba, su, genotip, Sistan, İran

Geliş Tarihi: 28.07.2015 Kabul Tarihi: 26.07.2016

Address for Correspondence / Yazışma Adresi: Dr. Hossein Hooshyar E.mail: hooshyar4@yahoo.com DOI: 10.5152/tpd.2016.4428

CCopyright 2016 Turkish Society for Parasitology - Available online at www.tparazitolderg.org

@Telif hakkı 2016 Türkiye Parazitoloji Derneği - Makale metnine www.tparazitolderg.org web sayfasından ulaşılabilir. 


\section{INTRODUCTION}

Members of Acanthamoeba genus are widely distributed in nature. Acanthamoeba species are isolated from soil, dust, air, drinking and mineral water, sea water, swimming pools, sewage, Jacuzzi tubs, aquariums, flower soil, surgery units, dentistry and dialysis units, ventilation/air conditioning units, contact lenses as well as from vegetables, fishes, reptiles, amphibians, birds, and humans (1). The life cycle of Acanthamoeba species includes two active trophozoite and cystic stages. A trophozoite in Acanthamoeba species can change into a cyst by switching its phenotype in harsh environmental conditions including lack of food, high temperature, unsuitable osmolarity, and other environmental stresses such as contact with antiseptic agents. Acanthamoeba species can retain its pathogenicity in suitable conditions and is transmitted to humans $(1,2)$. Acanthamoeba species causes human infection by polluted soil and water to cyst or trophozoite through dermal lesions or breathing organs by flowing air infected. Acanthamoeba pathogenic genotypes result in chronic human diseases including amoeba keratitis and the rare but deadly granulomatous amoebic encephalitis (GAE). Unlike GAE, Acanthamoeba keratitis infects healthy people after damaging the cornea, particularly in individuals using contact lenses. In addition, Acanthamoeba species can lead to pneumonia, sinus infections, and serious dermal lesions in individuals with immune system deficiencies (2). Till date, based on $18 \mathrm{~S}$ ribosomal DNA sequencing, 18 different genotypes of Acanthamoeba (T1-T18) have been identified. The most common pathogenic isolates are the T3, T4, and T5 genotypes (3). Most of the separated genotypes from clinical and environmental samples worldwide and in Iran belong to the T4 genotype, and it is the most important genotype isolated during amoeba keratitis and GAE (2-4).

The isolation of Acanthamoeba genotypes from environmental sources and human clinical cases has been reported from many parts of the world (3-6). Tanveer et al. (1) (2013) found seven pathogenic and non-pathogenic genotypes of Acanthamoeba in drinking water in Pakistan. Acanthamoeba genotyping has been performed in different environmental sources in Iran. A study by Rahdar et al. (5) for determining the Acanthamoeba genotype from environmental resources in Ahvaz city showed that from 110 water and soil samples, 43 water samples (71.6\%) and 13 soil samples (26\%) were infected with Acanthamoeba, species that genotype of 15 samples belonged to T4 (86.6\%), T2(6.6\%) and T5(6.6\%). Hooshyar et al. (6) investigated 40 stagnant water samples in Qazvin city and found that $43.8 \%$ of the surface water was infected by Acanthamoeba sp. That genotype of 11 samples (78.6\%) belonged to T4 and 3 samples (21.4\%) to T2.

According to previous studies, water resources are one of the most important risk factors for separated of this potential pathogen amoeba (5-7).

Objectives: Due to specific climatic conditions, Sistan and Balochistan regions are couple of the most important regions for studying the transmission of the pathogenic genotypes of this parasite. The aim of the present study was to detect and determine different genotypes of Acanthamoeba residing in stagnant water in Sistan region in southeast Iran using molecular biology techniques.

\section{METHODS}

\section{Sampling}

In this descriptive study, a total of 93 water samples from pools and ponds were randomly collected in Sistan region (Zabol, Zahak, Hirmand, Hamoon, and Nimrooz) in southeast Iran in 2014. All samples were collected in a receptacle $1000 \mathrm{~mL}$ screw cap tube and were transferred to the Parasitology and Mycology Laboratory, School of Medicine, Zabol University of School of Medicine.

\section{Filtration and cultivation}

Samples were filtered by a pumping machine through $0.45-\mu \mathrm{m}$ nitrocellulose paper filters. The sediment on filters in upside down way conveyed in $1.5 \%$ non-nutrient agar medium was prepared with amoeba page saline and covered by heat-killed Escherichia coli (7). The medium was completely blocked by parafilim and was placed at $27^{\circ} \mathrm{C}$. The plates was studied daily from the third day by light microscopy. Positive free-living amoeba plates were separated for conducting the next phases of the study, and due to the late growth of some free-living amoeba, other plates were kept and investigated for 1 month and were then removed from the study as negative samples.

\section{Harvesting amoeba from culture}

Harvesting amoeba from the medium established by sterile swab and adding $5 \mathrm{~mL}$ of phosphate-buffered saline (PBS) to the medium. The solution was transferred to a distinct bottle and was washed three times by sterile PBS $(\mathrm{pH}=7.2)$ at $2500 \mathrm{rpm}$ for $2.5 \mathrm{~min}$. Finally, the supernatant was removed and sediment (Figure 1) which having some enough amoeba for extracting DNA, transferred to $1.5-\mathrm{ml}$ micro-tubes and kept in a $-20^{\circ} \mathrm{C}$ freezer for further examination.

\section{DNA extraction and polymerase chain reaction (PCR)}

DNA extraction was performed using a Dyna Bio kit (Takapuzist, Iran). PCR was performed using a pair of specialized primers, JDP1 and JDP2, that amplified a 423 to 551-base pair fragment in $18 \mathrm{~S}$ ribosomal DNA specific to Acanthamoeba sp. (8). The sequences of these primers were as follows:

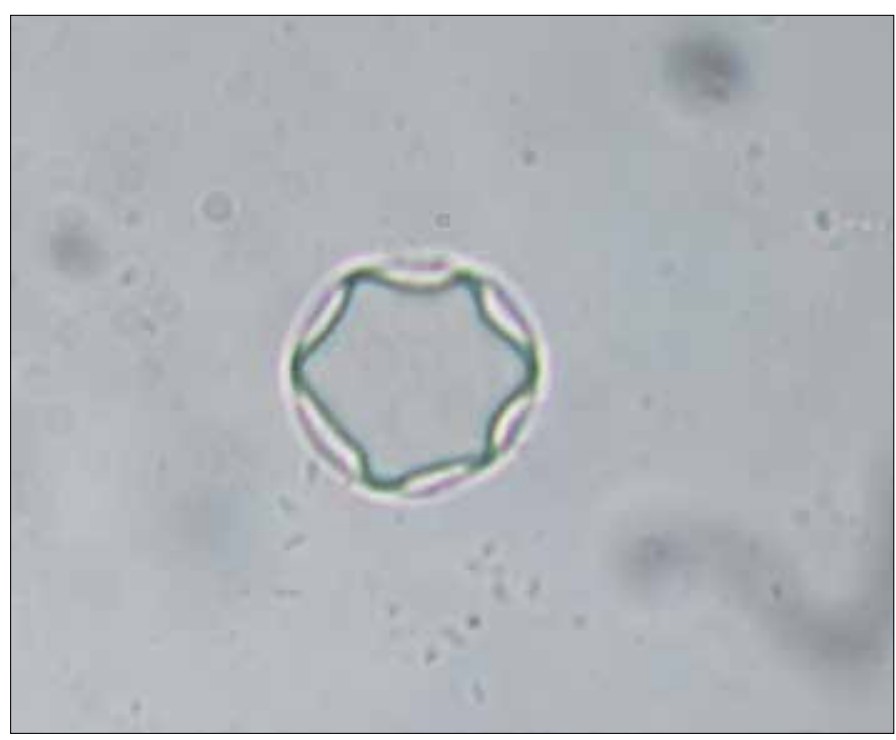

Figure 1. A free-living amoeba cyst from one of the studied ponds in Zabol city in non-nutrient agar medium (magnification, 400×) 


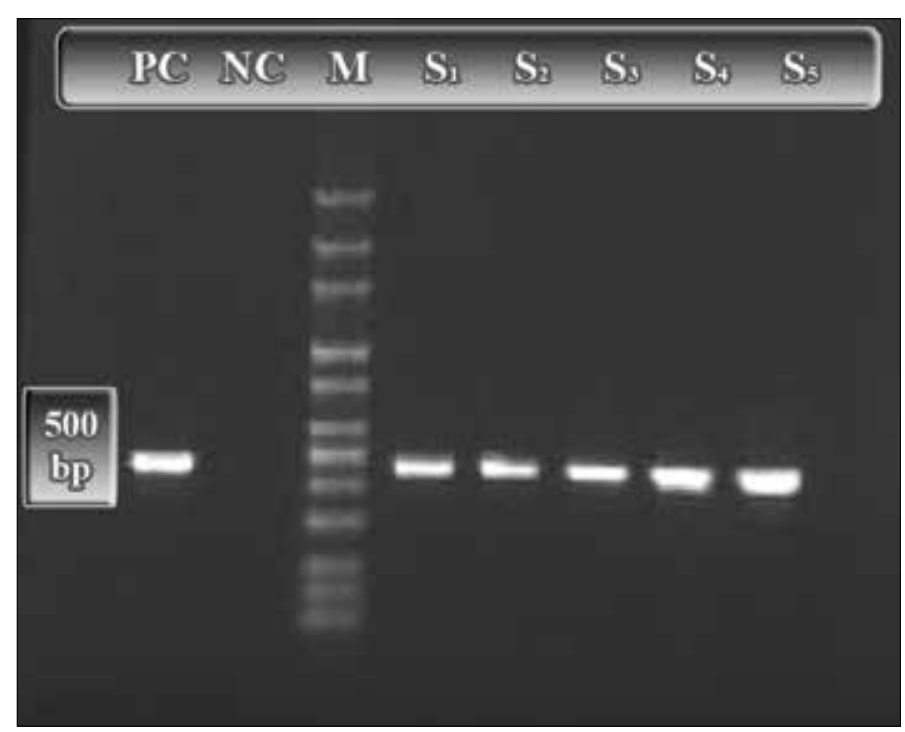

Figure 2. Electrophoresis of PCR products of Acanthamoebapositive samples from pools and pond water in Sistan region M: marker; PC: positive control; NC: negative control; S: sample

Table 1. Genotyping of 38 isolates of Acanthamoeba isolated from stagnant water in Sistan region in Iran in 2014

\begin{tabular}{|l|c|c|c|c|}
\hline $\begin{array}{l}\text { Genotype } \\
\text { City }\end{array}$ & $\begin{array}{c}\text { T4 } \\
\text { NO. (\%) }\end{array}$ & $\begin{array}{c}\text { T5 } \\
\text { NO. (\%) }\end{array}$ & $\begin{array}{c}\text { T3 } \\
\text { NO. (\%) }\end{array}$ & $\begin{array}{c}\text { Total NO. } \\
\text { (\%) }\end{array}$ \\
\hline Zabol & $20(90.1)$ & $1(4.5)$ & $1(4.5)$ & $22(100)$ \\
\hline Zahak & $4(80)$ & $1(20)$ & $0(0)$ & $5(100)$ \\
\hline Hirmand & $4(100)$ & $0(0)$ & $0(0)$ & $4(100)$ \\
\hline Nimrooz & $4(80)$ & $1(20)$ & $0(0)$ & $5(100)$ \\
\hline Hamoon & $2(100)$ & $0(0)$ & $0(0)$ & $2(100)$ \\
\hline Total & $34(89.47)$ & $3(7.9)$ & $1(2.63)$ & $38(100)$ \\
\hline
\end{tabular}

Forward-JDP1: (5'-GGCCCAGATCGTTTACCGTGAA)

\section{Reverse- JDP2: (5'-TCTCACAAGCTGCTAGGGGAGTCA)}

Polymerase chain reaction was performed in $20-\mu$ l volumes in 0.5 $\mathrm{mL}$ micro-tubes. The reaction mixture contained $10 \mathrm{mM}$ Tris- $\mathrm{HCl}$ ( $\mathrm{pH}=8.9$ ) (final concentration), $50 \mathrm{mM} \mathrm{KCl}, 1.5 \mathrm{mM} \mathrm{MgCl}_{2}, 200$ $\mathrm{nM}$ of each deoxynucleotide triphosphate (dNTP), $10 \mathrm{pmol}$ of each primer, and $0.25 \mathrm{~mL}$ of Taq DNA polymerase $(5 \mathrm{U} / \mathrm{mL})$, and $1-2 \mu$ of DNA.

Amplification was done using a thermocycler (Eppendorf, Germany) established by following application in 33 cycles: denaturation at $94^{\circ} \mathrm{C}$ for $35 \mathrm{~s}$, annealing at $57^{\circ} \mathrm{C}$ for $45 \mathrm{~s}$, extension at $72^{\circ} \mathrm{C}$ for $1 \mathrm{~min}$, and final extension at $72^{\circ} \mathrm{C}$ for $5 \mathrm{~min}$.

The PCR product was loaded on $1 \%$ agarose gel (containing 1 $\mathrm{ng} / \mathrm{mL}$ of ethidium bromide) by electrophoresis and was visualized under ultraviolet light (Gel Doc SYNCENE) for specific band identification.

\section{Acanthamoeba genotyping}

The sequencing of PCR products was conducted by an automatic sequencer (ABI 3730XL Genetic Analyzer, USA) in Takapuzist
(Takapuzist CO, Tehran, Iran). The results were analyzed using the Basic Local Alignment Search Tool in the National Center for Biotechnology Information database and by comparing with the sequence strains registered in GenBank for determining the genotypes of the isolates.

\section{Statistical analysis}

The results were recorded in data forms. For statistical analysis, Statistical Package for the Social Sciences 16.0 (SPSS Inc.; Chicago, IL, USA) was used for evaluation.

\section{RESULTS}

Of the 93 studied water samples, 82 samples (88.17\%) were positive for free-living amoeba. Acanthamoeba sp. was identified in 38 samples (46.34\%), which showed a 500-bp band using specialized primers JDP1 and JDP2 (Figure 2). Results of nucleotide sequencing showed 38 positive samples of Acanthamoeba in Sistan region, including 34 samples (89.47\%) belonging to the T4 genotype, three $(7.9 \%)$ to the T5 genotype, and one $(2.63 \%)$ to the T3 genotype (Table 1). The partial sequences of 26 isolates were registered in GenBank (Gl: 937943636-937943644, 957656390-957656396, 957516539-957516541, 930588826930588829, 965641757, 965641754, and 957656403).

\section{DISCUSSION}

The purpose of this study was to determine the prevalence and genotype of Acanthamoeba sp. in stagnant water in Sistan region in southeast Iran. Acanthamoeba sp. is abundant in environmental resources including stagnant water, swimming pools, and ponds. Human contact with this potential pathogenic amoebic parasite during daily life and an increasing number of contact lens users are risk factors for the transmission of Acanthamoeba to humans $(2,6,8)$. The results of this study demonstrated that pond water and many pools and (46.34\%) in Sistan region contain Acanthamoeba strains.

The prevalence of Acanthamoeba in different environmental sources has been studied in some regions of the world. The infection rate from Acanthamoeba has been reported to be $6.7 \%$ in public bathrooms in Hungary (9). The prevalences of Acanthamoeba in rivers water samples in America, Jamaica, Germany, and Bulgaria were $7 \%, 26.4 \%, 79 \%$, and $94 \%$, respectively (4). Acanthamoeba was isolated from $21 \%, 22.5 \%, 26.3 \%$, $36.1 \%$, and $59.5 \%$ of household water sources in Spain, Nicaragua, Japan, Brazil, and Mexico respectively (10-14).

Rezaeian et al. (15) reported that $46.25 \%$ of different environmental source samples in Tehran were infected with Acanthamoeba. A study by Hooshyar et al on surface stagnant water in Qazvin city found that $43.8 \%$ of the samples were infected with Acanthamoeba strains (6).

The results of nucleotide sequencing in this study showed that most isolates belonged to the T4 genotype (89.47\%), followed by the T5 genotype and the T3 genotype (7.9\%). All these genotypes are pathogenic and can causes dangerous infections such as GAE and amoeba keratitis $(2,3)$. Several studies have shown that the T4 genotype is the most prevalent genotype isolated from environmental and clinical samples in Iran and worldwide $(3,5,7,8,16)$. A study by Evyapan et al. (17) in 50 
water samples and 50 soil samples in Turkey showed that the T4, T3 and T15 genotypes were detected in water samples and the T4and T3 genotypes were detected in soil samples (17).

The T4 genotype was the predominant genotype (78.6\%) in surface stagnant water in Qazvin city (6). In addition, some studies on soil samples from parks in Tehran, water sources in Poland, and a keratitis patient in China showed that all samples studied belonged to the T4 genotype (18-20).

A study on 110 water and soil samples in Ahawaz showed that 43 water samples (71.6\%) and 13 soil samples (26\%) were infected with Acanthamoeba and that they belonged to the T4 (86.6\%), $\mathrm{T} 2(6.6 \%)$, and $\mathrm{T} 5(6.6 \%)$ genotypes (5).

The T4 genotype is the most prevalent genotype in environmental sources. This genotype is one of the most virulent genotypes and has an increasing importance due to its high range of distribution in environmental sources and the resistance of its cysts to antiseptics $(2,3)$.

The severity of disease in a person infected by the T4 genotype of Acanthamoeba will be enhanced as this genotype produces more cytotoxic factors than the T5, T3, and T2 genotypes (21).

The distribution and high prevalence of Acanthamoeba genotypes in pools and pond water in Sistan region are very important. The climatic condition of Sistan region is particular: blowing 120 day winds, lots of dust and dirt in air, little annual rainfall, and poor environmental water resources, which result in the increased transmission of this parasite and diseases arising from it. A study in Turkey showed that Acanthamoeba keratitis is associated with contact with domestic tap water in individuals who have ocular surface disease or ocular trauma in areas potentially endemic to Acanthamoeba (22). As the predominantly recognized genotype in present study is T4 and based on the fact that this genotype is one of the most important causes of Acanthamoeba infections, water resources in this study can be considered as an important source for the transmission of infection. Authorities and health managers should pay more attention in managing water resources, and the awareness of therapeutic system personnel in recognizing this amoeba should be increased. Sanitary principals and training health authorities and more investigation in environmental resources and clinical samples in this region will be effective on prevention of Acanthamoeba infections.

\section{CONCLUSION}

All genotypes found in this study are potentially pathogenic; the T4 genotype is the main genotype of Acanthamoeba responsible for amoebic keratitis. Resource water is a potential risk factor for the distribution of free-living amoeba. Therefore, more attention of health authorities to determine, training and prevention from infection are recommended.

Ethics Committee Approval: Ethics committee approval was not received for this study.

Informed Consent: Bu çalışma için hasta onamına gerek yoktur.

Peer-review: Externally peer-reviewed.
Author Contributions: Concept - A.A., H.H.; Design - A.A., H.H.; Supervision - H.H., M.D.; Funding - A.A., H.H., M.D.; Materials - A.A.; Data Collection and/or Processing - A.A., H.H.; Analysis and/or Interpretation - H.H., M.D.; Literature Review - Y.M.; Writing - H.H., A.A.; Critical Review - Y.M.; Other - A.A.

Acknowledgement: The authors would like to appreciate faculty members and personnel of parasitology departments in Zabol and Kashan Universities of Medical Sciences.

Conflict of Interest: No conflict of interest was declared by the authors.

Financial Disclosure: The authors declared that this study has received no financial support.

Etik Komite Onayı: Bu çalışma için etik komite onayı alınmamıştır.

Hasta Onamı: Not required in this study.

Hakem Değerlendirmesi: Dış bağımsız.

Yazar Katkıları: Fikir - A.A., H.H.; Tasarım - A.A., H.H.; Denetleme - H.H., M.D.; Kaynaklar - A.A., H.H., M.D.; Malzemeler - A.A.; Veri Toplanması ve/veya İşlemesi - A.A., H.H.; Analiz ve/veya Yorum - H.H., M.D.; Literatür Taraması - Y.M.; Yazıyı Yazan - H.H., A.A.; Eleştirel İnceleme - Y.M.; Other - A.A.

Çıkar Çatışması: Yazarlar çıkar çatışması bildirmemişlerdir.

Finansal Destek: Yazarlar bu çalışma için finansal destek almadığını belirtmiştir.

\section{REFERENCES}

1. Tanveer T, Hameed A, Gul Muazzam A, Jung S, Gul A, Matin A. Isolation and molecular characterization of potentially pathogenic Acanthamoeba genotypes from diverse water resources including household drinking water from Khyber Pakhtunkhwa, Pakistan. Parasitol Res 2013; 112: 2925-33. [CrossRef]

2. Rezaeian $M$, Niyyati M. Pathogenic free living amebas in human: Tehran University of Medical Sciences; 2008.

3. Khan NA. Acanthamoeba: biology and increasing importance in human health. FEMS Microbiol Rev 2006; 30: 564-95. [CrossRef]

4. Kao PM, Hsu BM, Chen CT, Huang SW, Kao ES, Chen JL, et al. Identification and quantification of the Acanthamoeba species and genotypes from reservoirs in Taiwan by molecular techniques. Acta tropica 2014; 132: 45-50. [CrossRef]

5. Rahdar M, Niyyati M, Salehi M, Feghhi M, Makvandi M, Pourmehdi $M$, et al. Isolation and genotyping of Acanthamoeba strains from environmental sources in Ahvaz City, Khuzestan Province, Southern Iran. Iran J Parasitol 2012; 7: 22-6.

6. Hooshyar H, Hoosinbagi B, Saraei M, Alizadeh S, Eftakhar M, Rasti $S$, et al. Genotyping of Acanthamoeba Isolated From Surface and Stagnant Waters of Qazvin, Central Iran. Iran Red Crescent Med J 2013; 15: 536-8. [CrossRef]

7. Niyyati M, Lorenzo-MoralesJ, Rezaie S, Rahimi F, Mohebali M, Maghsood AH, et al. Genotyping of Acanthamoeba isolates from clinical and environmental specimens in Iran. Exp Parasitol 2009; 121: 242-5. [CrossRef]

8. Schroeder JM, Booton GC, Hay J, Niszl IA, Seal DV, Markus MB, et al. Use of subgenic $18 \mathrm{~S}$ ribosomal DNA PCR and sequencing for genus and genotype identification of Acanthamoebae from humans with keratitis and from sewage sludge. J Clin Microbiol 2001; 39: 903-11. [CrossRef]

9. Kiss C, Barna Z, Vargha M, Török JK. Incidence and molecular diversity of Acanthamoeba species isolated from public baths in Hungary. Parasitol Res 2014; 113: 2551-7. [CrossRef] 
10. Leiva B, Clasdotter E, Linder E, Winiecka-Krusnell J. Free-living Acanthamoeba and Naegleria spp. amebae in water sources of León, Nicaragua. Rev Biol Trop 2008; 56: 439-46.

11. Lorenzo-Morales J, Ortega-Rivas A, Foronda P, Martınez E, Valladares B. Isolation and identification of pathogenic Acanthamoeba strains in Tenerife, Canary Islands, and Spain from water sources. Parasitol Res 2005; 95: 273-77.[CrossRef]

12. Edagawa A, Kimura A, Kawabuchi-Kurata T, Kusuhara $Y$, Karanis P. Isolation and genotyping of potentially pathogenic Acanthamoeba and Naegleria species from tap-water sources in Osaka, Japan. Parasitol Res 2009; 105: 1109-17. [CrossRef]

13. Magliano AC, da Silva FM, Teixeira MM, Alfieri SC. Genotyping, physiological features and proteolytic activities of a potentially pathogenic Acanthamoeba sp. isolated from tap water in Brazil. Exp Parasitol 2009; 123: 231-35. [CrossRef]

14. Bonilla-Lemus P, Ramírez-Bautista GA, Zamora-Munoz C, IbarraMontes R, Ramírez-Flores E, Hernández-Martínez MD. Acanthamoeba spp. In domestic tap water in houses of contact lens wearers in the metropolitan area of Mexico City. Exp Parasitol 2010; 126: 54-8. [CrossRef]

15. Rezaeian, M, Niyyati M, Farnia Sh, Motevalli Haghi A. Isolation of Acanthamoeba Spp. from Different Environmental Sources. Iran J Parasitol 2008; 3: 44-7.
16. Lorenzo-Morales J, Ortega-Rivas A, Martınez E, Khoubbane M, Artigas P, Periago MV, et al. Acanthamoeba isolates belonging to T1, T2, T3, T4 and T7 genotypes from environmental freshwater samples in the Nile Delta region, Egypt. Acta Trop 2006; 100: 63-9. [CrossRef]

17. Evyapana G, Koltasa I S, Eroglub F. Genotyping of Acanthamoeba T15: the environmental strain in Turkey. Trans R Soc Trop Med Hyg 2015; 109: 221-4. [CrossRef]

18. Lass A, Szostakowska B, Idziñska A, Chomicz L. The first genotype determination of Acanthamoeba potential threat to human health, isolated from natural water reservoirs in Poland. Parasitol Res 2014; 113: 63-9. [CrossRef]

19. Ebrahimi M, Niyyati M, Haghighi A, Haydari S. Isolation and genotyping of Acanthamoeba spp.from recreational soil of parks in Tehran, Iran. Armaghane-danesh, 2013; 4:530-8.

20. Zhao G, Sun S, Zhao J, Xie L. Genotyping of Acanthamoeba isolates and clinical characteristics of patients with Acanthamoeba keratitis in China. J Med Microbiol 2010; 59: 462-6. [CrossRef]

21. Hajialilo E, Niyyati M, Solaymani M, Rezaeian M.Pathogenic free-living amoebae isolated from contact lenses of keratitis patients. Ianian J Parasitol 2015; 10: 541-6.

22. Koltas IS, Eroglu F, Erdem E, Yagmur M, Tanır F. The role of domestic tap water on Acanthamoeba keratitis in non-contact lens wearers and validation of laboratory methods. Parasitol Res. 2015; 114:3 [CrossRef] 